\title{
THE COMMON HISTORY OF EUROPEAN LEGAL SCHOLARSHIP
}

\author{
Tammo Wallinga*
}

\begin{abstract}
This paper traces the common history of European legal scholarship from its beginning in the late 12 th century to the development of national codifications which started some six centuries later. During this period, Roman law was of great importance in the universities, and Justinian's Corpus Iuris Civilis was the central text for legal studies. We will look at the different approaches to this body of text that legal scholarship has taken over the years. Still, Roman law did not have a complete monopoly: we will have a look as well at Canon law and Moral Theology, which also developed a system of legal norms, but on an entirely different basis. They paved the way for Natural law, which - in a critical dialogue with Roman law - paved the way for modern codifications.
\end{abstract}

Keywords: Roman law, Corpus Iuris Civilis, Glossators, School of Orléans, Commentators, Canon law, Moral Theology, School of Salamanca, Legal Humanism, Usus modernus Pandectarum, Natural law, Historical School, Pandectenwissenschaft

\section{Introduction}

Europe is not a small place, its legal scholarship has a long history, and for many parts of Europe it is a common history. One may say that, for centuries, there was a European legal scholarship, until the appearance of national codifications caused lawyers to focus mainly on their own national law. This contribution will therefore focus on the period between the emergence of universities in continental Europe (starting with the legendary founding of the University of Bologna in 1088) and the development of national codifications of law from the 18th century onwards. It will be historical rather than methodological, if only for the simple reason that there has to be legal scholarship before we can look for a method in it and because the development of methodology as a specific branch of academic activity is only a relatively recent phenomenon.

A significant part of the contribution will be devoted to the reception of Roman law. This implies a focus on private law - which may easily be defended, since private law has by far the longest history of all areas of the law. In continental Europe, Roman law, in the form of the Emperor Justinian's Corpus Iuris Civilis, was by far the most important element in legal training from the Middle Ages to the times of the national codifications, and as such it retains a certain importance even today. Moreover, with local laws and customs being rather fragmentary in most places, Roman law had a part to play in legal practice, as subsidiary law. This means that the Corpus Iuris Civilis was, for many centuries, the main point of reference for lawyers all over Europe, even if its exact role has varied with time. In the era of the Glossators (ca. 1100-1260) it was mainly a tool for university education, and much energy was spent on making it more readily accessible with their commentaries and through a system of cross-referencing. The School of Orléans, which blossomed in the 13th century, paved the way for a freer interpretation of its texts. The Commentators (or Post-Glossators, ca. 1260-1500) built on the methods of both the Glossators and the School of Orléans, and started to use the Corpus Iuris Civilis in legal practice as well, as a source of law - which raises interesting questions about the relative authority of statute law, local customs and Roman law. Legal Humanism (ca. 1500-1750) started to challenge the authority of Roman law by calling into question the textual basis of the Corpus Iuris Civilis through the application of a much more fundamental method of textual criticism. It also introduces another methodological innovation in that it tried to arrange the texts of the Corpus Iuris Civilis

\footnotetext{
Tammo Wallinga is Associate Professor of Legal History at the Erasmus Universiteit Rotterdam and Professor for History of Private Law at the Universiteit Antwerpen.
} 
in a logical system, that of Justinian's Institutiones, which derived from the work of the Roman lawyer Gaius. A kind of synthesis of the methods of the Commentators and Legal Humanism was achieved in the Usus modernus Pandectarum (16th-18th centuries). And finally, the German Historical School and its offspring, the Pandectenwissenschaft, carried out a late but very important re-examination of Roman law in order to develop new technical concepts and an improved systematisation, which made possible the German codification of private law in the Bürgerliches Gesetzbuch (BGB) of 1900.

Roman law did not have a complete monopoly, however. Especially during the Middle Ages, canon law was another important part of the curriculum in the universities. It made a major contribution to the development of legal procedure. In the field of private law, it helped to develop a general law of contract and a general concept of tort/delict. Key to these important contributions was the influence of moral theology, especially that of the works of Thomas Aquinas. The application of principles of moral theology to law blossomed especially in the Spanish School of Salamanca (16th century), which in turn had considerable influence on natural law. Canon law and moral theology form an interesting contrast to Roman law: their approach is based on general principles, unlike Roman law, which mostly consists of case-law originating in a system of specific actions.

Natural law is a third important approach to law. It is already present in canon law and moral theology in the shape of general principles with an essentially theological background. Secularised by Hugo Grotius and turned into a rational approach to law in the 17th century, it became a competitor for Roman law in the universities, where chairs for natural law were established in the late 17th and 18th centuries. It contributed to the criticism on Roman law and paved the way for the national codifications that were the eventual outcome of the Enlightenment.

As we provide a more detailed overview of the reception of Roman law below, we will devote special attention to two interesting, methodological points. First, if Roman law was so important as a vehicle for legal teaching, to what extent did it earn a place in practice, where it had to compete with statute law and customary law? What exactly was its place among the possible sources of law that a judge would apply to the case he had to decide? Second, how did legal scholars who were trained in Roman law, which is essentially case-law, manage to eventually develop codifications of private law that consist of general rules forming part of a system of law?

\section{Roman Law; Justinian's Corpus Iuris Civilis}

There is a continuous line of development of legal scholarship on the European continent, starting in the Middle Ages. The starting point lies in Bologna, a university founded against the background of the power struggle between the German emperor and the pope and the rise to prosperity of many cities in Northern Italy. Following Charlemagne's example, the German emperor presented himself as the successor to the Western Roman emperor, and found a certain amount of support for his claims to power in the Roman legal texts. The Emperor Frederick Barbarossa employed a large number of Bolognese lawyers to determine his exact rights in Italy. And the economic growth of the cities meant increasing employment for lawyers, not least in the function of podestà: an outsider - not a member of one of the local rivalling families - as the highest magistrate, someone who of course needed to have a solid legal training. This was the market that the University of Bologna - and others, of course - catered for.

The central text in legal education, especially in the early centuries, was the major text of Roman law: the Corpus Iuris Civilis of the (Eastern) Roman Emperor Justinian (527-565). Under his aegis, three important works were compiled in 528-534 in Constantinople: the Codex Justinianus (first published in 529 and in a revised edition in 534, containing legal advice and decisions issued by Justinian's predecessors and by himself), the Institutes (an introductory work for beginning students, but with force of law, based on the Institutes of the Roman jurist Gaius written around 160 AD) and the Digest (or in Greek: pandectae; a collection of fragments from the works of the Roman jurists of the classical period, ca. 100 BC-250 AD, issued as one constitution of Justinian). After the publication of these works, Justinian continued to issue new 
constitutiones which are called Novels (novellae); a collection of 168 of these together with the three works mentioned earlier forms what is called the Corpus Iuris Civilis. ${ }^{1}$

The Institutes, Digest, Codex and a collection of Novels extant at the time were taken to Italy when Justinian's generals had managed to gain control over a good part of it in a campaign that had started in 534. The texts were given force of law in Italy, supposedly at the request of Pope Vigilius, in $554 .^{2}$ Little is known about their exact fate during the next five centuries. What is certain, however, is that towards 1100 Justinian's Corpus Iuris Civilis formed the basic text for legal education in civil law ${ }^{3}$ as this was taking shape in the Studium of Bologna. Legal education at university spread across the European continent, and its tradition remains unbroken until today. For much of that period, the Roman legal texts formed the mainstay of the legal curriculum. ${ }^{4}$

We will first look at the way the Roman legal texts were used in teaching at medieval universities. It is common to distinguish three - not radically, but still different approaches to the Roman texts: that of the Glossators, the School of Orléans and the Commentators. We will follow this distinction and treat all three in turn.

\section{Glossators ${ }^{5}$}

The beginning of this first period is traditionally put at 1088, the year considered by the University of Bologna to be the year of its foundation. The end is the death in 1263 of Accursius, who brought together the glosses produced during the first century and a half of legal scholarship in his Glossa ordinaria around 1260. Of course, this does not mean that the methods employed by jurists suddenly changed dramatically after 1263 though it is true that the writing of new glosses went out of fashion after Accursius.

Much of the work done by scholars from this period consisted in writing glosses to the text of the Corpus Iuris Civilis. The glosses - notes in the margins and sometimes between the lines of the Justinianic texts - range from simple explanations of words and alternative readings of the text to thorough analysis of the legal contents. They provide the professor with material for his classes. The Glossators made the first efforts to come to grips with the rather unstructured work that the Corpus Iuris is. Apart from providing commentaries in their glosses, they set up a system of references (allegationes) that made it easier to relate texts on the same subject matter from the Institutes, Codex, Digest and Novels to each other. In accordance with Justinian's instructions, they tried to interpret the texts in such a way that no contradictions Justinian's compilers had actually left plenty of these - remained. ${ }^{6}$ This they achieved by grouping together the texts in favour of and against a certain argument or rule, and then interpreting some texts as the rule and others as the exceptions to it by means of distinctions. The approach is essentially a-historical: the Glossators studied the Corpus Iuris Civilis as one body of authoritative texts and were not interested in the inscriptiones of the Digest, which provide information about individual jurists and make it possible to give each his own place in the historical development of Roman law.

Apart from the glosses, there are several other types of legal literature, partly originating in the teaching of the Corpus Iuris Civilis at university. ${ }^{7}$ Some follow the

\footnotetext{
J.H.A. Lokin and W.J. Zwalve, Hoofdstukken uit de Europese codificatiegeschiedenis (The Hague 2006).

2 Sanctio pragmatica pro petitione Vigilii, to be found at the end of the Schoell and Kroll edition of Justinian's Novels.

Civil law is used here as meaning the received Roman law, as opposed to canon law.

P. Koschaker, Europa und das römische Recht (Munich 1958).

G. Wesenberg and G. Wesener, Neuere deutsche Privatrechtsgeschichte (Vienna/Cologne 1985) at 2228; E. Cortese, Il diritto nella storia medievale. II: Il basso Medioevo (Rome 1995); H. Lange, Römisches Recht im Mittelalter, Band I, Die Glossatoren (Munich 1997); H. Schlosser, Grundzïge der Neueren Privatrechtsgeschichte, Rechtsentwicklungen im europäischen Kontext (Heidelberg 2005) at 36-53.

Const. Tanta § 15; P. Stein, Regulae iuris. From Juristic Rules to Legal Maxims (Edinburgh 1966) at 131-132.

P. Weimar, 'Die legistische Literatur und die Methode des Rechtsunterrichts der Glossatorenzeit' (1969) 2 Ius Commune 43-83; P. Weimar, 'Die legistische Literatur der Glossatorenzeit' in H. Coing (ed.),
} 
ordo legum, that is, they treat the texts in the order in which they are found in Justinian's works. This is the case for the commentum, later called lectura, which is essentially a report of the lectures given by a professor, written down by an experienced student or assistant and sometimes revised by the professor himself. The older commentum is normally somewhat condensed, whereas the lectura is a full report of all what was said and done in the lecture hall, including remarks of the reportator about the behaviour of the students and the stories, jokes and gossip about their colleagues that the professors would tell to enliven their lectures. Another type of literature is the written record of the quaestio disputata: this was meant to teach students to analyse a problem and to argue their case in a structured plea. The question could either be a purely theoretical one or one taken from legal practice. ${ }^{8}$

Another kind of commentary, which does not have its origin in the classroom, is the summa. Summae are summaries, mostly of entire titles of the Corpus Iuris. Unlike the commenta or lecturae, they are systematic works, even if the system does not extend beyond the scope of the title in hand. The oldest ones are not from Bologna, and many are from France - the reason being that the production of books was less well organised there than in Bologna. Azo wrote a number of summae on different parts of the Corpus Iuris, to which others were added during the first half of the 13th century, to form a standard summa on the entire Corpus Iuris. No new summae were written after that. ${ }^{9}$ It must be stressed that the summae are different from the commenta and lecturae in that they do not follow the order of the text in the Corpus Iuris but - at least within the title they treat - establish their own order and system to treat the fragments within the title. To some extent, the summae paved the way for the later systematic approach of the Legal Humanists.

Apart from these works, there were also short monographs about specific topics: summulae or tractatus. And an important category is formed by the literature about the law of procedure: ordines iudiciarii. The Corpus Iuris Civilis does not contain a specific comprehensive section on the law of procedure; the ordines iudiciarii sought to compile all the relevant material on procedure in general and on specific actions, and provided instructions on how to produce a writ. One of the most influential works of this kind is the Speculum iudiciale of Wilhelmus Durantis $( \pm 1270)$.

The Glossators saw Justinian's Corpus Iuris as valid law for their own time, since it was of imperial origin. Consequently, they did not hesitate to add constitutions of the German Emperors Frederick Barbarossa and Frederick II to the Codex. Apparently they had no problems with accepting the validity of texts from a fairly distant past in their own day. And not because they were ivory tower jurists unaware of the realities of legal practice: many Glossators can be shown to have been active as legal advisers, advocates or judges. However, little or nothing of their practical experiences shines through in their commentaries on the Corpus Iuris, which remained a rather isolated object of their academic interest: they did not pay attention to legal norms outside it, like statute law or customs. If they used the Corpus Iuris in practice - which in itself is not unlikely - the fact has remained unrecorded in their writings.

There was a strong connection between the Glossators and the emperor, in the sense that Roman law provided the emperor with a historical basis for his claim to power. Charlemagne (742-814) had been the first to claim that he was in fact the heir to the throne of the Western Roman emperor - much to the dismay of the Byzantine emperor - and this ideology had been taken up again by Otto I (912-973) when he became German emperor in 962. ${ }^{10}$ Frederick Barbarossa (1122-1190, emperor since 1152) employed a good number of Bolognese professors as his legal advisers in his conflicts with the Italian cities and granted them privileges, e.g. exemption from ordinary

Handbuch der Quellen und Literatur der neueren europäischen Privatrechtsgeschichte. I: Mittelalter (1100-1500), Die gelehrten Rechte und die Gesetzgebung (Munich 1973) at 129-258.

F.P.W. Soetermeer, "Une catégorie de commentaires peu connue. Les "commenta" ou "lecturae" des précurseurs d'Odofrède' (1991) 2 Rivista Internazionale di Diritto Comune 47-68.

A famous phrase about it is chi non ha Azzo non va a palazzo - he who doesn't have Azo should not go to the Palace (of Justice). See E.J.H. Schrage, Utrumque Ius. Eine Einführung in das Studium der Quellen des mittelalterlichen gelehrten Rechts (Berlin 1992) at 58-59.

10 Koschaker, above n. 4, at 38-54. 
jurisdiction (Authentica Habita). ${ }^{11}$ However, one thing that neither Frederick Barbarossa nor his successors ever did was declare Justinian's Corpus Iuris to be valid law. The legend that Roman law had been introduced in Germany through a law of the Emperor Lothar II (1125-1137) has been proven to be false by Conring. ${ }^{12}$

Irnerius ( $\dagger$ after 1125) is the oldest Glossator to whom certain glosses can be attributed. Differences of opinion among Glossators can be demonstrated as early as the 12th century, with Bulgarus de Bulgarinis ( $\dagger 1166)$ and Martinus Gosia ( $\dagger$ ca. 1160 ) - two of the so-called Quattuor Doctores - as famous adversaries. Bulgarus eventually turned into a kind of founding father of the 'mainstream' of the Glossators, who stuck closely to the text in their interpretation, with Martinus and his pupils representing the dissident line, which preferred a more liberal interpretation based on the principles of good faith, possibly inspired to some extent by canon law. Bulgarus' pupil Johannes Bassianus was the teacher of Azo ( $\dagger$ ca. 1220), who in turn was the teacher of Accursius ( $\dagger$ 1263). The latter is responsible for what came to be the culminating work of the period: around the middle of the 13th century he compiled a dense apparatus ${ }^{13}$ of glosses on the entire Corpus Iuris, using all the material that had been prepared since the beginning of the 12th century. This Glossa ordinaria or Accursian Gloss became the standard commentary on the Corpus Iuris for many centuries to come. With it, writing glosses had reached its zenith and the attention of legal scholars shifted to different approaches, made possible because the Corpus Iuris had by now been completely cross-referenced and provided with a full commentary.

\section{Methodological Aspects: The Scholastic Method; ${ }^{14}$ Sources}

The essential medieval scientific method is the scholastic method, or dialectics: formal logic applied to an authoritative text. Just as the theologians dealt with the Bible as their main text, and the students of Medicine with Galenus, the jurists had the Corpus Iuris of Justinian. The objective was to be able to read the text as a logical unit. In the case of the Corpus Iuris, this involved finding a way of harmonising texts containing opposite opinions about or solutions for the same legal problems. In the introductory constitutions to his codification, Justinian had foreseen this problem of antinomiae, and had given the legal world the imperial solution: that in fact there were none, provided one interpreted his books with sufficient subtlety. This is exactly what the medieval civilists ${ }^{15}$ set out to do. The same happened in canon law: the very title of Gratian's Decretum (Concordantia discordantium canonum) indicates that it is about harmonising texts that disagree with one another - see below.

The formal logic applied was largely based on a work by Abélard, Sic et non, written around 1120. This was an important and influential book, in which Abélard applies the principles of formal logic laid down by Aristotle ${ }^{16}$ to texts of the Church fathers. He juxtaposes contrasting texts, points out the differences of opinion and treats them in a critical, dialectic manner without giving a final decision. Sic et Non contains a philological method applied to authoritative texts. It raises a series of common doubts: has the text been corrupted, has the author made a mistake, do we really

\footnotetext{
11 W. Stelzer, 'Zum Scholarenprivileg Friedrich Barbarossa's (Authentica "Habita")' (1978) 34 Deutsches Archiv für Erforschung des Mittelalters 123-165.

12 H. Conring, De origine iuris germanici (Helmstedt 1643). Two centuries earlier, the Italian Humanist Lorenzo Valla had proved that the famous Donatio Constantini, which supported the claim that the Emperor Constantine had transferred power over the Western Roman Empire to the Pope when he set up a new capital in the East, was in fact a forgery. See W. Setz, Lorenzo Vallas Schrift gegen die Konstantinische Schenkung (Tübingen 1975).

13 An apparatus being a full commentary - as opposed to incidental glosses - which fills the margins around the text.

14 M. Grabmann, Die Geschichte der scholastischen Methode I-II (Freiburg i.Br. 1909-1911; reprinted Basel/Stuttgart 1961); G. Otte, Dialektik und Jurisprudenz, Ius commune, Beiheft 1 (Frankfurt am Main 1971).

15 I.e. lawyers working in civil law, as opposed to canonists.

16 That is, the works of Aristotle that were known at the time: the Logica vetus. This consisted of Latin translations, partly made by Boethius in the Vth century, and by further translations of Arabic translations.
} 
understand him ${ }^{17}$ Texts are grouped in function of their similarity (similia) or contrariety (contraria) and reasoning per analogiam or a contrario is applied, with distinctions (distinctiones) being established that explain the differences between the groups. This so-called scholastic method could be applied to any authoritative text, whether in the field of theology, medicine, philosophy or law, and it reigned supreme in the Middle Ages, without, however, becoming extinct in later ages - in fact, it remains an important part of legal reasoning to this very day.

As far as the sources of law are concerned, Schrage notes that among civil lawyers in the Middle Ages there was no specific hierarchy of the sources of law. There was a distinction between civil and natural law, but neither of the two was seen as more important than the other. It is not until Azo in the Summa that anyone puts forward the idea that some sources of law are more important than others: Azo - remarkably for a civil lawyer - singles out the decisions of the great Councils of Nicaea, Constantinople, Ephesus and Chalcedon as more important than other rules. It seems that the idea of a hierarchy of sources of law has a Christian background, and through canon law influenced medieval civil law as well. ${ }^{18}$

\section{School of Orléans ${ }^{19}$}

The School of Orléans may be traced back to 1235 as a place where legal education was organised; it was upgraded to a university in 1306. It had already won fame in the 13th century: Thomas Aquinas mentions Paris, Bologna, Salerno and Orléans as the four great studia generalia of his day. The first professors were Frenchmen and Italians who had studied at Bologna, and may well have belonged to the opponents of Accursius. Later there were some important figures who had had their training in France, like Jacques de Revigny (Jacobus de Ravanis, †1296) and Pierre de Belleperche (Petrus de Bellapertica, $\dagger$ 1308). They had more interest in legal theory than the Italian Glossators and a more historical approach to the Roman legal texts. Revigny is known to have criticised the Glossators for sticking too closely to the text of the Corpus Iuris Civilis and for ignoring the ratio of a given passage. The members of the School of Orléans also had their eyes wide open for legal practice: they gave examples taken from contemporary cases. And they contributed to non-Roman areas of law, like international private law and penal law.

In their approach to Justinian's Corpus Iuris, they were generally more original than the Italian Glossators, and they treated its texts with more freedom. Revigny and Belleperche are known to have considered the views of canon law. An important innovation by Revigny was the creation of the legal person - later to become known as a persona repraesentata among the Commentators in Italy. It must be noted, however, that this particular subject was extensively treated by canon law as well; Revigny appears to have shared an interest with canon lawyers for a number of different topics.

Eventually, the works of the School of Orléans were to form a source of inspiration for the Commentators in the 14th century; Cinus de Pistoia, in particular, speaks with great respect about Revigny and Belleperche and quotes them frequently. Though it continued to be an important centre of learning in France, the heyday of the School of Orléans was apparently over by then - although this may also be due to the fact that the later period of the history of this school remains rather underinvestigated. ${ }^{20}$

\footnotetext{
17 J. Huizinga, 'Abaelard' Handelingen en levensberichten van de maatschappij der Nederlandsche letterkunde te Leiden 1934-1935 [s.1., s.a.] 66-82 at 78.

18 E.J.H. Schrage, 'Rechtsquellen aus der Sicht der Glossatoren' in Iuris vincula. Studi in onore di Mario Talamanca (Naples 2001) VII 409-424 at 416 and 423.

19 E.M. Meijers, 'De universiteit van Orléans in de XIIIe eeuw' (1918-1919) 1 Tijdschrift voor Rechtsgeschiedenis 108-132 and 443-488, (1920-1921) 2 Tijdschrift voor Rechtsgeschiedenis 460-508; French translation in Meijers, Etudes d'Histoire du Droit I-IV, R. Feenstra and H.F.W.D. Fischer (eds.) (Leiden 1956-1966) III, 3-148; Wesenberg and Wesener, above n. 5, at 29; H. Lange and M. Kriechbaum, Römisches Recht im Mittelalter. Band II, Die Kommentatoren (Munich 2007) 130-137, 518-567.

20 Only recently has a thorough study on the School of Orléans in the 14th century been published: M. Duynstee, L'enseignement du droit civil à l'université d'Orléans du début de la guerre de cent ans (1337) au siège de la ville (1428), Studien zur europäischen Rechtsgeschichte 253 (Frankfurt am Main 2010).
} 
The Ultramontani (the French lawyers at Orléans, but also at Montpellier and Toulouse) used essentially the same methods as their Italian colleagues at Bologna, even if they may have been a bit more adventurous in applying them, and wrote the same types of legal literature. Many summae were written in France, perhaps because book production was less well organised there, meaning that copies of the Corpus Iuris Civilis were not readily available. ${ }^{21}$

One genre that blossomed especially at Orléans was the repetitio: a separate lecture on especially difficult texts. These were not treated in the context of the normal lectures, but at another time, in the afternoon. During the repetitio, the central text (sedes materiae) was studied in connection with other texts, which in the end often gave rise to a complete and systematic treatment of a certain theme. Some form of systematic treatment of the law is therefore also found in the School of Orléans.

\section{Post-Glossators, Commentators and Conciliators ${ }^{22}$}

The representatives of the direction that legal scholarship took after the Glossators are often simply called Post-Glossators - a name that apparently does not give them much credit for any achievements in their own right. A more favourable name would be Commentators, and - with reference to the important activity of many of them as legal advisers who wrote consilia - Conciliators has been suggested as well. There is no clean break; the Commentators built on the work of the Glossators and the School of Orléans. The three most important figures among the Commentators are Cinus de Pistorio (†1336), whose tribute to Revigny and Belleperche has already been mentioned, Bartolus de Saxoferrato $( \pm 1314-1357)$, a pupil of Cinus, and Baldus de Ubaldis $( \pm 1327-1400)$. Bartolus became the emblematic lawyer of his time, immortalised in the expression nemo iurista nisi Bartolista - nobody is a lawyer unless he is a follower of Bartolus.

Accursius' Glossa ordinaria is the watershed between Glossators and Commentators. It is the culminating point of a century and a half of legal learning, but also forms a point of reference for the future. The new era of the Commentators saw more involvement with legal practice, a further development of the dialectic method helped by the fact that new translations of the works of Aristotle, some of them unknown thus far (Logica nova), became available - and the spreading of the learned law (Ius commune) across Europe.

The time of the Commentators saw the true beginning of the reception of Roman law. With economic prosperity and development in the Italian cities during the 11th13th centuries, the need for legislation had been met by local authorities with a great mass of local statutes. Together with all sorts of local customs, this did not make the picture any simpler: sources of law were many, inconsistent and incomplete. Given this situation, Roman law had a part to play as a more complete legal system in the background, a framework that could serve to assign local statutes and customs a place within a greater whole. At the same time, lawyers with university training in Roman law were ready to meet the demand for legal expertise in everyday practice. Legal thinking along Roman lines became increasingly important, a development both promoted and underlined by the establishing of high courts of law that were manned by lawyers schooled at university: the Parlement de Paris (1273), the Great Council of Malines (1473) and the Reichskammergericht (1495). The fact that Roman law was of imperial origin was an important factor, but it started to impose itself by the sheer weight of its intellectual authority as well.

The increased attention for legal practice is visible in the genre of the quaestio disputata: from the middle of the 13th century onwards, the Bolognese professors

${ }^{21}$ On the organisation of book production in the Middle Ages, see F.P.W. Soetermeer, Utrumque ius in peciis: die Produktion juristischer Bücher an italienischen und französischen Universitäten des 13. und 14. Jahrhunderts (Frankfurt am Main 2002).

22 N. Horn, 'Die juristische literatur der Kommentatorenzeit' (1969) 2 Ius Commune 84-129; N. Horn, 'Die legistische Literatur der Kommentatoren und der Ausbreitung des gelehrten Rechts' in Coing, above n. 7, at 261-364; Wesenberg and Wesener, above n. 5, at 28-39; Lange and Kriechbaum, above n. 19. Following Lange and Kriechbaum, the name Commentators will be used. 
increasingly based their quaestiones on local statute law or even customary law, which were thus analysed by means of the methods of civil law.

Giving legal advice and being active in legal practice was not necessarily a new development that started with the Commentators, but they certainly showed more of their practical activities in their writings. The consilium - the academic advice of a law professor on a practical problem - became probably the most important form of legal literature of the time. Baldus made a name for himself as conciliator; according to the - not entirely reliable - printed editions, he wrote almost 2500 consilia. Judges were often obliged to ask for a consilium before giving their decision. In the consilia, the difficult mixture of local statutes and customs is tackled through the techniques of interpretation and argumentation of the Roman lawyers. In other words, through the consilium the science of Roman law based on the Corpus Iuris acquired an important influence on legal practice. Roman law was used as the main argument; statute law was treated within its context, mainly as a deviation from it, and experienced a Romanising influence as a result.

Typical of the Commentators is also that they were more inclined to take their cue from a specific theme or question (materia) rather than from a text of the Corpus Iuris. The corresponding form of literature is the tractatus, which consequently is not structured in function of the texts of the Corpus Iuris; the structure follows from the materia and incorporates texts from the Corpus Iuris as they fit the arguments and counter-arguments. Thus, the Commentators worked further towards a more synthetic and systematic use of the texts of the Corpus Iuris. A useful tool for them to achieve this was the last title of the Digest: De diversis regulis iuris antiqui, about different rules of ancient law. It contains 211 fragments which each consist of one or more rules or maxims. This title was considered to be a kind of summary of the entire contents of the Digest. 23

In the time of the Commentators, there was a stronger connection between civil law and canon law. Baldus, for instance, wrote commentaries both on Civil and canon law. In the 14th century, it became customary for students to study both subjects and thus become doctor utriusque iuris, doctor of both laws.

\section{Canon law ${ }^{24}$}

During the Middle Ages, canon law was every bit as important as civil law, both in practice and at university, specifically in the fields of family law, contracts, testaments and the law of civil procedure. Canon law courts had a far from negligible jurisdiction.

Originally, canon law had no manageable corpus of text comparable to civil law's Corpus Iuris Civilis. This changed around 1140, when a monk called Gratianus made a collection of texts of very diverse origin - writings of the Church fathers, decisions of Councils, texts from the Bible - which is officially called Concordantia discordantium canonum (harmonisation of disagreeing canones), but is usually known as the Decretum Gratiani. Given the character of its source material, it gained great authority, even if it was only a private collection and not an official codification. It provided a comprehensive and systematic collection of canon law, trying to bring together all the law of the Church into one systematic whole.

After the publication of the Decretum, the popes kept making laws, taking administrative decisions and giving sentences as judges. These texts (decretales) were later gathered together in other collections. The Liber Extra is a collection of decretals in five books, published in 1234 by Pope Gregorius IX. It was followed in 1298 by a collection of decretals of Bonifatius VIII (and his predecessors), called the Liber Sextus. Both these collections are real codifications of canon law: they were officially issued as such by these two popes, and to make sure that they would be applied in practice they were sent to the university of Bologna with the urgent recommendation that students of canon law should study them and apply them in practice after their studies. Together with the Decretum they form the bulk of the Corpus Iuris Canonici, which additionally contains decretals of Pope Clemens V dating from 1317

\footnotetext{
23 Stein, above n. 6, at 148.

24 K.W. Nörr, 'Die kanonistische Literatur' in Coing, above n. 7, at 365-382; Schrage, above n. 9, at 90109. See also J. Brundage, Medieval Canon Law (London 1995).
} 
(Clementinae), decretals (Extravagantes) of Pope Johannes XXII (1316-1334) and some more decretals of later popes (Extravagantes communes). These three further sets of texts were never officially issued as codifications and consequently did not quite have the authority of the earlier ones.

In material law, canon law made a significant contribution to the development of a general law of contract. In civil law, contracts were treated as separate categories, each with its own action or actions that defined the legal consequences of the contract. An agreement that could not be brought under one of the predefined categories was no contract in civil law, and therefore - in principle - not actionable. Canon law applied the principle that all agreements should lead to actionable obligations: pacta sunt servanda, a famous phrase that can be traced back to the Council of Carthage of 348 $\mathrm{AD}^{25}$ and that was reinforced by a passage from the Gospel of Matthew (5:37): "But let your "Yes" be "Yes" and your "No" be "No". Whatever is more than these is of the evil one. ${ }^{, 26}$ In other words, a good Christian should always be true to his word. ${ }^{27}$

The same general approach - as opposed to one based on specific actions - was applied by canon law, supported by moral theology, to the field of compensation for damage caused. Rather than applying a number of actions, each with its own specific and limited reach, canon law considered that anyone who through his fault (culpa) caused damage to another should pay the latter compensation. This eventually - Hugo de Groot's work is an important link here, as we shall see below - led to the general approach we find in modern codifications, such as the French Code civil (Art. 1382) and the Dutch civil codes of 1838 (Art. 1401) and 1992 (Art. 6:162).

Canon law - together with civil law - also did much for the development of the law of procedure. This was a particularly poorly treated subject in the Corpus Iuris Civilis, which contains no specific section on procedure in general - there are many smaller sections on aspects of the law of procedure, but they are scattered all over the Corpus Iuris Civilis. These smaller sections were eventually brought together into systematic overviews of the law of procedure, often called ordines iudiciarii. The most influential of these is the Speculum iudiciale of Wilhelmus Durantis $( \pm 1270)$. Canon law contributed much to the discussion about general principles of the law of procedure that helped to construct these ordines iudiciarii.

The method of canon law is essentially the same as that of civil law. ${ }^{28}$ The official title of the Decretum expresses very well what it was about: reconciling apparently disagreeing texts so as to form one authoritative whole. This was done with the help of the well-known dialectics: through arguments per analogiam and a contrario and by establishing distinctiones that explained the differences between the texts that were in agreement with each other and those that expressed another view. There were summae as well, the most important one being written in the middle of the 13th century by Hostiensis - it is full of references to civil law, giving the author the well-deserved name of monarcha utriusque iuris, the king of both laws.

Just like civil law, canon law ended up developing more or less systematically treated doctrines. It did so, however, on the basis of different source material - the Corpus Iuris Canonici - and while concentrating on different themes: especially the law of persons and family law.

\section{Moral theology ${ }^{29}$}

Moral theology is a branch of theology that concerns itself with moral questions, which it tries to answer in the light of the Christian faith. It is concerned with good and bad in

\footnotetext{
25 The relevant text may be found in the Liber Extra: X 1:35:1.

26 Translation from World English Bible.

27 Cf. A. Söllner, 'Die causa im Vertragsrecht des Mittelalters bei den Glossatoren, Kommentatoren und Kanonisten' (1960) 77 ZRG Rom. Abt. 182-269 (partly reprinted in E.J.H. Schrage, Das römische Recht im Mittelalter, Wege der Forschung 635 (Darmstadt 1987) 131-186.

28 Stein, above n. 6, at 132; cf. W. Fikentscher, Methoden des Rechts in vergleichender Darstellung. Band I: Frühe und religiöse Rechte (Tübingen 1975).

29 R. Feenstra and L.C. Winkel, Vergelding en vergoeding. Enkele grepen uit de geschiedenis van de onrechtmatige daad (Deventer 2002) at 15-17; the central text of Thomas Aquinas is Summa Theologiae, Secunda Secundae, Quaestio 62, art. 2 ad secundum; in his Opera omnia (Rome 1897) 42-43.
} 
human behaviour and typically centres more on what man is supposed to do than - as dogmatic theology does - on what he is supposed to believe. To that extent it comes quite close to law, which also concerns itself with questions of what is wrong or right, or what should be done in practical situations where people come into conflict with each other. Sources of moral theology are the Old and New Testament, but may also be found in a not specifically religious area, like philosophy, especially ethics, and natural law.

The greatest figure in moral theology, without any doubt, is Thomas Aquinas ( \pm 1225-1274). His most important work is the Summa theologiae, a manual for beginning students of theology on all aspects of the relationship between God and man. It contains many passages about legal subjects. In Part I, Thomas writes about natural law, defined as man's participation in God's eternal law, which can be discovered through reason. It is derived from general principles, like the promotion of good and avoidance of evil. Part II of the Summa contains Thomas's ethics, which are to a large extent derived from the ethical works of Aristotle. Thomas was able to profit from recently made - possibly at his request - translations of the works of Aristotle by Willem van Moerbeke, which had made available several works that had not been in circulation before.

Important for law is Thomas's doctrine of restitution. Building on Aristotle's Ethica Nicomachea, on the one hand, and on Saint Augustine, on the other, it states the very general principle that whenever anyone through his fault has caused another to have less than what is due to him, he must restore (restituere) the latter to his original position. When this is not physically possible, he must pay him a compensation in money. Causing damage to another is a sin (peccatum) which cannot be forgiven before restitution has taken place. ${ }^{30}$ This is a very general approach that fits a great number of different situations and may be applied to both contracts and torts or negligence. It is a totally different approach than that of Roman law, where specific actions with a limited reach determine both the law of contracts and that of the delicta privata. Thomas based himself on Aristotle's concepts of iustitia distributiva and iustitia commutativa in the Ethica Nicomachea. The role of the iustitia distributiva is to establish an initial situation of equality, where every man has a position and goods in accordance with his worthiness and talents. Whenever this equality is disturbed, it is the role of the iustitia commutativa to rectify the situation and make sure that the initial order is restored. Legal actions, therefore, may be considered as individual manifestations of the general principle of iustitia commutativa.

The thing to note about the doctrine of restitution is that it lays down a general approach to the law of obligations, equally applicable to the law of contracts as to the law of tort, negligence or delict. It is on a far higher level of abstraction than the Roman case-law built around the specific actions on a limited number of contracts and delicts.

\section{School of Salamanca ${ }^{31}$}

Moral theology continued to base itself on the doctrines of Thomas Aquinas (Thomism) for a long time, until early in the 16th century when the traditional ideas about man and his relationship with God and the world started to be challenged by Humanism, Protestantism and the discovery of the New World. The School of Salamanca took up these challenges and tried to provide an answer to them. It was a school of theologians and jurists who intended to reconcile Thomism with the new social and economical order. Its most famous representatives are Francisco de Vitoria ( \pm 1483-1546), Martín de Azpilcueta (1492-1586), Domingo de Soto (1494-1570) and Fernando Vázquez (1512-1569). The main objects of study of the School were man and his practical problems of a moral, economical or legal nature.

\footnotetext{
30 This idea is expressed in a letter by Saint Augustine incorporated in the Decretum Gratiani (C. 14 q. 6 c. 1) and repeated in the regula Peccatum in the Liber Sextus (VI 5:12:4).

31 O.W. Krause, Naturrechtler des 16. Jahrhunderts. Ihre Bedeutung für die Entwicklung eines natürlichen Privatrechts, Diss. Göttingen 1949 (Frankfurt am Main 1982) 39-101; cf. G. Nufer, Über die Restitutionslehre der spanischen Spätscholastiker und ihre Ausstrahlung auf die Folgezeit, Diss. Freiburg im Breisgau (1969).
} 
The School did important work in the field of economics; it is considered to be the founder of economic science. ${ }^{32}$ But for law it was at least as important. The members of the School developed a theory of natural law that yielded interesting conclusions: equality and human rights and the idea that sovereignty rests with the people, which can transfer it to the monarch. Vitoria developed a theory about ius gentium and thus became the founder of public international law. Another creation of the School are theories about just war. And finally, some of its members took part in the famous debate between Juan Ginés de Sepúlveda and Bartolomé de las Casas about the legitimacy of the conquest of the New World (Junta de Valladolid, 1550-1551).

The ideas of the School of Salamanca reached the Netherlands (in the broad sense of the term) along different lines. One of these is the Jesuit Lenaert Leys (Leonardus Lessius, 1554-1623) of Louvain. During his studies in Rome he had met one of the members of the School of Salamanca, Francisco Suárez (1548-1617) with whom he remained in correspondence. Lessius taught moral theology for years at the Jesuit studium at Louvain, introducing the ideas of the School of Salamanca. For the weekly debates about ethical questions he used a work by Martín de Azpilcueta (alias Doctor Navarrus, 1492-1586). He was known for his clear style of writing; one of his works was De iustitia et iure ceterisque virtutibus cardinalibus (1605). In the Northern Netherlands, it seems that Hugo de Groot (Grotius) was inspired by Domingo de Soto's De iustitia et iure, which he had brought to him when he was a prisoner at Loevestein castle in 1619. He also quoted from the works of Azpilcueta. It was through Grotius that the general principles of moral theology would cross over from theology to law. ${ }^{33}$

\section{Legal Humanism ${ }^{34}$}

Legal Humanism - a new approach to civil law - was inspired by the general spirit of inquisitiveness and no longer taking things for granted that ended the Middle Ages and ushered in another era. It is characterised by a great interest in classical antiquity and a desire to get to know it directly from the sources. Rather than just studying the legal texts, the Humanists developed an interest in their historical and linguistic background.

Legal Humanism had two periods during which it blossomed, in two different places: it started in France in the 16th century, especially at the University of Bourges. Some important figures who must be named in this context are Guillaume Budé (Budaeus, 1468-1540), Andrea Alciato (Alciatus, 1492-1550) and Jacques Cujas (Cuiacius, 1522-1590). More than a century later, it was prominent again in to the Republic of the Netherlands, roughly from 1670-1730. The young, prospering Republic attracted the interest of scholars from many countries through the high academic level of its antiquarian approach to the Roman legal sources, known as the Dutch Elegant School. ${ }^{35}$ Perhaps the greatest figure is Gerard Noodt (1647-1725, professor at Leyden from 1706), but outside the ranks of university professors we must also mention Henrik Brenkman (1681-1736), who worked for many years on a new edition of the Digest that he never managed to finish; his notes, however, form the

\footnotetext{
32 J. Schumpeter, History of Economic Analysis (New York 1954) 94-115.

33 See R. Feenstra, 'L'influence de la scolastique espagnole sur Grotius en droit privé: quelques expériences dans des questions de fond et de forme, concernant notamment les doctrines de l'erreur et de l'enrichissement sans cause' in La Seconda Scolastica nella formazione del diritto privato moderno, Incontro di studio, Firenze, 16-19 Ottobre 1972, Atti [= Per la storia del pensiero giuridico moderno, 1] (Milano 1973) at 377-402, reprinted in R. Feenstra, Fata Ivris Romani, Études d'histoire du droit (Leiden 1974) at 338-363.

34 G. Kisch, Humanismus und Jurisprudenz. Der Kampf zwischen mos italicus und mos gallicus an der Universität Basel (Basel 1955); H.E. Troje, 'Die Literatur des gemeinen Rechts unter dem Einfluss des Humanismus' in H. Coing (ed.), Handbuch der Quellen und Literatur der neueren europäischen Privatrechtsgeschichte. II: Neuere Zeit (1500-1800), 1. Teilband, Wissenschaft (Munich 1977) 615-795; Wesenberg and Wesener, above n. 5, at 60-71.

35 G.C.J.J. van den Bergh, Die holländische elegante Schule, ein Beitrag zur Geschichte von Humanismus und Rechtswissenschaft in den Niederlanden 1500-1800, Studien zur europäischen Rechtsgeschichte 148 (Frankfurt am Main 2002).
} 
basis of the important edition by Gebauer and Spangenberg, ${ }^{36}$ and Mommsen's preface to his editio maior of the Digest owes much to Brenkman's book Historia pandectarum. $^{37}$

With Legal Humanism, there began a completely different approach to the Corpus Iuris Civilis. The Legal Humanists were interested in the historical context of the texts of the Corpus Iuris and tried to read them against that background, relating them to the information provided by non-legal sources from antiquity. The typical publication in this field is the observatio, a short essay in (elegant) Latin making a specific point. ${ }^{38}$ Also, they tried to return to the oldest possible version of the texts and find the manuscripts that would help them to do so: ad fontes (back to the sources) sums up this approach. For the Digest, in particular, this meant an increased interest in the elusive Codex Florentinus, which was eventually reproduced in a kind of quasi-facsimile edition by Francisco and Lelio Torelli in $1553 .{ }^{39}$ Another innovation was that, unlike their medieval predecessors, Humanists did read Greek texts (Graeca leguntur), ${ }^{40}$ which enabled them, for instance, to use manuscripts of the Basilica ${ }^{41}$ to improve the text of the Corpus Iuris. The new historical and critical approach to the legal texts came to be known as the mos gallicus as opposed to the traditional Bartolistic method, the mos italicus. ${ }^{42}$ It was not necessarily welcome in legal practice; quite the contrary. Practical lawyers did not like any doubt being cast on the texts they used to base their arguments on.

The Legal Humanists were also responsible for the beginnings of interpolation criticism and palingenesia. Interpolation criticism aims at eliminating the changes made to the legal texts from the classical period of Roman law (roughly $100 \mathrm{BC}-250$ $\mathrm{AD}$ ), when they were inserted into the Digest by Justinian's compilers. This is not easy to do with any degree of certainty unless one has an uninterpolated text for comparison, and over the centuries some scholars have been overzealous in assuming interpolations. Whatever the merit of early interpolation criticism, it certainly strengthened the impression that the text of Justinian's codification was anything but perfect.

Palingenesia profits from the fact that every fragment of the Digest is provided with an inscriptio giving the name of the original author and where in which work of that author the fragment belonged. They allow a sort of reconstruction of the original works - always with the Justinianic text - to the extent that fragments from them were used in the Digest. The modus operandi is simple: separate all the fragments contained in the Digest, maintaining the inscriptiones, sort them by jurist and then for each jurist sort them by work and then by book (e.g. Ulpianus, libro octavo decimo ad edictum). The project was begun by Jacobus Labittus at the instigation of Cujas: he made a list of authors with references both to texts of those authors contained in the Digest and to passages in the texts of other authors where they are mentioned. He did not yet try to restore the original order in the works of individual jurists; this was only done in the 19 th century by Lenel, the author of a more definitive Palingenesia. ${ }^{43}$

36 Corpus iuris civilis ... recensuit Georgius Christianus Gebauer, et post ejus obitum editionem curavit Georgius Augustus Spangenberg (Gottingae 1776-1797).

37 H. Brenkman, Historia Pandectarum seu Fatum Exemplaris Florentini [...], Trajecti ad Rhenum, apud Guilielmum van de Water (1722). The Codex Florentinus is the manuscript of Justinian's Digest, probably written in the 530s in Constantinople and therefore considerably older than the manuscripts normally used by the Glossators and Commentators. It was taken by the Florentines from the Pisans in 1406 and been jealously guarded in Palazzo Vecchio ever since; very few scholars at the time got a chance to see it.

38 Troje, above n. 34, at 671-689.

39 The famous Torelli edition is Digestorum seu pandectarum libri quinquaginta ex Florentinis pandectis repraesentati, curavit Laelius Taurellus, Florentiae, in officina Laurentii Torrentini (1553).

40 H.E. Troje, Graeca leguntur. Die Aneignung des byzantinischen Rechts und die Entstehung eines humanistischen Corpus iuris civilis in der Jurisprudenz des 16. Jahrhunderts (Cologne/Vienna 1971).

41 The Basilica are a Greek integrated version of Justinian's Digest and Codex made by the Byzantine Emperor Leo the Wise around the year 900. Its text contains many fragments of literal Greek translations of the Digest and Codex.

42 F. Carpintero, "Mos italicus", "mos gallicus" y el Humanismo racionalista. Una contribución a la historia de la metodología jurídica' (1977) 6 Ius Commune 108-171.

43 J. Labittus, Index legum omnium quae in Pandectis continentur [...] (Paris, A. Wechelus 1557); O. Lenel, Palingenesia iuris civilis, I-II (Leipzig 1889). 
Given that Justinian's compilers only retained 5 per cent of the available texts, the Palingenesia was never going to achieve a complete reconstruction of the original works. However, in the case of jurists of whose works much has been used, it is possible to get a good impression what the structure of a given work was. Thanks to the Palingenesia, separate Digest fragments may be read within their original context, which can be very helpful for their interpretation. Thus it serves both a legal and an historical purpose.

Apart from this more antiquarian approach, there was also a tendency - already noticeable especially among the later Commentators but now becoming more important - to try and achieve a more systematic treatment of the contents of the Corpus Iuris. The medieval summae and repetitiones had introduced systematic treatment for one title at a time, but now it was attempted to present the entire Corpus Iuris as one systematic whole. Justinian's Institutes were chosen as a model, since they are the only part of the Corpus Iuris Civilis containing a real system, derived from that of the Institutes of Gaius (ca. 160 AD). ${ }^{44}$ The most famous example of such a new systematic treatment is the commentary of Hugues Doneau (Donellus, 1527-1591), ${ }^{45}$ though the method was also applied to other material than the Corpus Iuris, notably by Charles Dumoulin (Molinaeus, 1500-1566) to the customary law of Paris (Cô̂tume de Paris) and by Hugo de Groot to the law of Holland. ${ }^{46}$

Another point that affects legal methodology is the fact that the critical approach of the Humanists slowly but surely eroded the authority of Roman law. On the one hand, the hunt for new manuscripts had revealed many doubts about the exact wording of certain passages. On the other hand, the desire of the Humanists to re-establish the classical text of the Roman jurists suggested that the traditional Justinianic text was not, in fact, the real thing. This made Roman law vulnerable in the competition with other legal sources, especially natural law. Its authority, which had once rested on that of the (German) emperor, now came to be based on its intrinsic quality, where it had not been explicitly challenged. The change is summed up in a Latin play on words: Roman law applied non ratione imperii, sed imperio rationis (not for reason of its authority, but for the authority of Reason). ${ }^{47}$

\section{Natural law ${ }^{48}$}

During the 17th and 18th centuries, natural law became an increasingly serious competitor for Roman law, and it would eventually make an important contribution to the national codifications that would put an end to the direct application of Roman law in practice. ${ }^{49}$

The idea of natural law as an all-encompassing system of law may be traced back as far as the ancient Greek philosophers. Roman lawyers - under the influence of the Stoa - treated it as well, mainly as a body of law equally observed by all peoples, and therefore also called ius gentium. The Church father Aurelius Augustinus (354-430)

\footnotetext{
44 It was impossible for them to use Gaius directly, because the text of his Institutes was not rediscovered until 1816.

45 Hugonis Donelli Iurisconsulti, Commentariorum de iure civili libri viginti octo [...], Francofurti, apud Andr. Wecheli heredes, Claudium Marnium et Joan Aubrium, 1595-1597.

46 Ch. Dumoulin, Commentaria in consuetudines Parisienses (Paris: Poncet le Preux 1539); Hugo de Groot, Inleidinge tot de Hollandsche Rechts-Geleertheyd (1631).

47 G.C.J.J. van den Bergh, Geleerd recht. Een geschiedenis van de Europese rechtswetenschap in vogelvlucht (Deventer 2007) at 87.

48 C. von Kaltenborn, Die Vorläufer des Hugo Grotius auf dem Gebiete des Ius naturae et gentium, sowie der Politik im Reformationszeitalter (Leipzig 1848; reprinted Frankfurt am Main 1965); Chr. Bergfeld, 'Johann Gottlieb Heineccius und die Grundlagen seines Natur- und Völkerrechts' in J.G. Heineccius, Grundlagen des Natur- und Völkerrechts (Frankfurt am Main 1994) 507-532; L. Danneberg, 'Die Auslegungslehre des Christian Thomasius in der Tradition von Logik und Hermeneutik' in F. Vollhardt (ed.), Christian Thomasius (1655-1728). Neue Forschungen im Kontext der Frühaufklärung (Tübingen 1997) 253-316; H. Thieme, Das Naturrecht und die europäische Privatrechtsgeschichte (Basel 1954, 2nd ed.); H. Thieme, 'Die Zeit des späten Naturrechts' (1936) 56 ZRG Germ. Abt. 202 ff.; H. Welzel, Naturrecht und materiale Gerechtigkeit (Göttingen 1962, 4th ed.).

49 Schlosser, above n. 5, at 84-142.
} 
promoted the idea of a divine origin of the law, just after Christianity had become the state religion of the Roman empire (380). The Latin Bible thus became the main source of natural law. We have already seen that Thomas Aquinas (1224/1225-1274) later developed a legal philosophy - also inspired by the works of Aristotle (384-322) which derived law from the ideal order of God's creation (ordo Dei). During the 16th century, as we have also seen, Thomas's philosophy was adapted by the so-called Secunda Scholastica of the School of Salamanca. The Spanish doctrine of natural law which maintained a theological basis - had an important influence on legal philosophy and even on dogmatic aspects of law, since it treated specific contemporary problems from a natural law point of view.

The Dutchman Hugo Grotius (1583-1645) - who deserves to be singled out because of the important influence he had on other lawyers in various countries - continued the tradition of the School of Salamanca, but was responsible for an important change: he developed the idea of a rational natural law based on human intellect (ratio). In his famous and influential work De iure belli ac pacis (1625) he carefully states that even if we were so bold as to suppose that there is no God, there would still be valid natural law. ${ }^{50}$ The idea of a rational natural law was developed further by the German lawyer Samuel Pufendorf (1632-1694), who completely separated natural law from any theological foundation. Pufendorf built up a legal system more geometrico, by a method inspired on natural sciences, deducing its rules from a number of axioms.

This rational natural law became an important source of criticism on Roman law. The monopoly of Roman law in university education was undermined by the institution of chairs in natural law from the middle of the 17th century onwards - a case in point being Pufendorf's chair in Heidelberg (1661). In Germany, Christian Thomasius (1655-1728) and Christian Wolff (1679-1754) developed it further. In France, Jean Domat (1625-1696) applied natural law principles in his book Les lois civiles dans leur ordre naturel (1689). The different designs for a natural law system paved the way for the codifications brought about by the political developments and events of the 18th century. An early one was the Bavarian Codex Maximilianeus Bavaricus of 1756; it was followed in Prussia by the Allgemeines Landrecht für die Preussischen Staaten (ALR, 1794), by the famous French Code civil (1804) and the Austrian Allgemeines Bürgerliches Gesetzbuch (ABGB, 1811). Introduction of a codification always entailed putting an explicit end to the application of Roman law in practice - however, since it remained an important subject in most universities, its intellectual life as a legal lingua franca continued, and has done so until now.

\section{Usus modernus Pandectarum ${ }^{51}$}

If Legal Humanism was the fashionable way to work with the Corpus Iuris Civilis in the 16th and 17th centuries, in the background there were many more lawyers who used it from a purely practical point of view, continuing the medieval tradition of the mos italicus. The work of the Legal Humanists had made some difference through better editions of texts, and historical arguments also made their way into practice to some extent, but the methods of the practitioners remained largely unaffected. In Germany, this practical approach came to be known as the Usus modernus Pandectarum, a name taken from the identical title of a book by Samuel Stryk (16401710), published in 1690 .

50 De iure belli ac pacis, Prolegomena 11. About the influence of Hugo de Groot's work on others, see R. Feenstra, 'Grotius' Doctrine of Liability for Negligence: Its Origin and Its Influence in Civil Law Countries Until Modern Codifications' in E.J.H. Schrage (ed.), Negligence: The Comparative Legal History of the Law of Torts (Berlin 2001) at 129-171.

51 A. Söllner, 'Usus modernus Pandectarum' in Coing, above n. 34, at 501-516; Wesenberg and Wesener, above n. 5, at 115-119; Schlosser, above n. 5, at 76-83; R. Voppel, Der Einflu $\beta$ des Naturrechts auf den Usus modernus (Cologne etc. 1996); W. Wiegand, 'Die privatrechtlichen Rechtsquellen des Usus modernus' in D. Simon (ed.), Akten des 26. Deutschen Rechtshistorikertages (Frankfurt am Main 1987) at 237-252; J. Schröder, 'Die privatrechtliche Methodenlehre des Usus modernus' in Simon, id., at 253-278; D. Willoweit, 'Der Usus modernus oder die geschichtliche Begründung des Rechts. Zur rechtstheoretischen Bedeutung des Methodenwandels im späten 17. Jahrhundert' in D. Willoweit (ed.), Die Begründung des Rechts als historisches Problem (Munich 2000) at 229-245. 
This is a wide-ranging term. In its broadest sense, it can refer to any modern and even contemporary use of Roman law - especially the Digest, also known as the Pandectae - as a source of law, such as we still find in South-Africa or Sri Lanka. In a narrower, more technical sense, it refers to the approach of positivist German lawyers in the 17th and 18th centuries. Superficially, it appears to be a continuation of the Bartolist method of the mos italicus; yet something had changed, largely due to the critical approach to Roman law initiated by the Legal Humanists. The Usus modernus Pandectarum developed a different doctrine about the sources of law. The tone was set by Hermann Conring (1606-1681) in his De origine iuris Germanici (1643), and Stryk also makes it clear in the introduction to his Usus modernus Pandectarum: whereas Roman law has a part to play as a source of law, the position of local law is now different: it is to be studied for its own sake. During the Middle Ages, lawyers had also found themselves having to deal with several sources of law, including Roman law and local law, but they would tend to look upon local law as an aberration from Roman law. The Usus modernus instead saw it as a further development of Roman law through custom. This approach ensured a much stronger position of local law in comparison to Roman law, which lost its pivotal position among the sources of law. Scientific study of local law began with the Usus modernus Pandectarum.

As far as Roman law is concerned, the name Usus modernus Pandectarum is significant, especially the first two words. Usus implies that the aim is to apply Roman legal texts in practice and not to make a scientific study of them. Modernus further implies that it was related to what applied in contemporary law. The representatives of the Usus modernus may have taken some benefit from the work of the Legal Humanists, but they used the Roman texts unhistorically, as just another source of legal norms. It was not, incidentally, limited to Germany; many French and Dutch lawyers worked along the same lines. A case in point, to give but one example, is the wellknown work of Simon van Groenewegen, De legibus abrogatis, in which he investigates which Roman law texts may still be considered to be applicable law in the Netherlands. ${ }^{52}$

There was no consistency in the Usus modernus as to which Roman legal texts were thought to apply. Some Usus modernus lawyers were quick to assume that a Roman rule no longer applied, whereas others would presume its applicability and required proof of the contrary.

\section{The German Historical School / Pandectenwissenschaft ${ }^{54}$}

It is an ironic twist of fate that the German codification, the Bürgerliches Gesetzbuch (BGB) of 1900, was profoundly influenced by the works of a man who in 1814 strongly argued against the feasibility of a codification. In that year, Professor Anton Friedrich Justus Thibaut of Heidelberg had put forward the idea of carrying out a general civil law codification (including private, penal and procedural law) for

\footnotetext{
52 S. van Groenewegen van der Made, Tractatus de legibus abrogatis et inusitatis in Hollandia vicinisque regionibus. Lugduni Batavorum, apud Davidem Lopez de Haro et Franciscum Moyardum (1649). There is a recent edition with an English translation: B.Z. Beinart and M.L. Hewett, A Treatise on the Laws Abrogated and No Longer in Use in Holland and Neighbouring Regions by Simon à Groenewegen van der Made, I-IV (Johannesburg 1974-1989). Groenewegen followed French examples, see L. Winkel, 'Some Remarks on Groenewegen's De legibus abrogatis and the Reception of the Roman Law of Sale' in R. van den Bergh (ed.), Summa Eloquentia. Essays in Honour of Margaret Hewett, Fundamina, Editio specialis (Pretoria 2002) at 271-275.

53 G.C.J.J. van den Bergh, Geleerd recht. Een geschiedenis van de Europese rechtswetenschap in vogelvlucht (Deventer 2006) at 74 et seq.

${ }_{54}$ Wesenberg and Wesener, above n. 5, at 170-213; U. von Lübtow, 'Savigny und die Historische Schule' in Festschrift zum 125 jährigen Bestehen der Juristischen Gesellschaft zu Berlin (Berlin/ New York 1984) at 381-406; Schlosser, above n. 5, at 143-156; J. Schröder, 'Zum Einfluss Savignys auf den allgemeinen Teil des deutschen Bürgerlichen Rechts', review of Horst Hammen, Die Bedeutung Friedrich Carl v. Savignys für die allgemeinen dogmatischen Grundlagen des Deutschen Bürgerlichen Gesetzbuches (Berlin 1983) (1985) 14 Quaderni Fiorentini 619-633.
} 
Germany, in order to promote national political unity. ${ }^{55} \mathrm{He}$ made no secret of his admiration for the French Code civil (which at the time applied in parts of Germany west of the Rhine). That same year, a Professor of Roman and Civil law in Berlin, Friedrich Carl von Savigny (1779-1861), wrote an eloquent and famous answer, Vom Beruf unserer Zeit für Gesetzgebung und Rechtswissenschaft, in which he argued that Germany was not ready for codification, and that much work still needed to be done before a successful codification could be carried out in Germany. ${ }^{56}$ Whether the delay is entirely due to Savigny is debatable, but the fact remains that it took almost another century before the BGB came into force and Germany obtained its unified civil law.

Savigny's theory is a reaction to the pretensions of rational natural law as a product of the Enlightenment, just as Romanticism in art and literature was a reaction to the dry intellectualism of the previous era. He was, in fact, closely related to such famous German romantic figures as Von Arnim and Brentano, having married the latter's sister Kunigunde in 1804. In Vom Beruf, Savigny laid down most of the programme for the Historical School, which he officially founded in 1815, together with his Berlin colleague Karl Friedrich Eichhorn (1781-1854). They edited the programmatic journal of the school, the Zeitschrift für geschichtliche Rechtswissenschaft - the predecessor of the modern Savigny-Zeitschrift.

In Vom Beruf, Savigny opposes the idea that law can be constructed in a mathematical way, more geometrico. In his view, the law of a nation is as characteristic of that nation as its language. It is not made for the people, but grows organically with the people; it is a historical phenomenon - Roman law being the most eminent example. A codification, therefore, can only be successful if it builds on the historical tradition of the law of the people, and intimate knowledge of this tradition is essential for carrying out the right codification. This knowledge of the historical tradition - or rather the lack of it - is pointed out by Savigny as the great weakness in Germany and, consequently, as the main obstacle to a successful codification. His conclusion is that the only way to achieve a better law for Germany is to have a legal scholarship that proceeds organically and studies the tradition from the beginning. And this is exactly what he and his pupils did, starting with the medieval reception of Roman law in Italy. In fact, Roman law - in its Justinianic form - was found to be an important common element in the law of many German countries, especially since it had been applied by the common German Supreme Court, the Reichskammergericht, since its foundation in 1495 .

Roman law, however, was studied not so much for its own sake, but with a view to the future. Savigny's pupils used Roman law, and especially the Digest or Pandectae, to develop general notions that the Romans themselves had never used, like legal act (Rechtsgeschäft) or legal capacity (Geschäftsfähigkeit). This form of legal scholarship came to be known as Pandektenwissenschaft. One of its most famous representatives, Bernhard Windscheid (1817-1892), wrote a manual that has still not lost its importance, and he later became a central figure in the committee that would prepare the BGB. In the German BGB (1900), we find yet another form of reception of Roman law. The BGB certainly is a codification that is much more closely related to Justinian's than, for instance, the French Code civil, even if it is almost a century further removed from Justinian in time. It is the most recent example of the influence of Roman law on the formation of modern private law.

\section{Concluding remarks}

It is intriguing to see how long Roman law has been a major point of reference both in legal practice and in the academic training of jurists in (continental) Europe - and that it remains so as a subject in the legal curriculum in many countries.

\footnotetext{
55 A.F.J. Thibaut, 'Rezension über August Wilhelm Rehberg, Ueber den Code Napoléon und dessen Einführung in Deutschland (Hannover 1814)' in Heidelbergische Jahrbücher der Litteratur, 7 (1814) at 132; and especially: A.F.J. Thibaut, Ueber die Nothwendigkeit eines allgemeinen bürgerlichen Rechts für Deutschland (Heidelberg 1814).

56 F.C. von Savigny, Vom Beruf unserer Zeit für Gesetzgebung und Rechtswissenschaft (Heidelberg 1814).
} 
Let us return to the two points that were raised at the end of the introduction to this article. As far as the role of Roman Law in legal practice goes, we have seen that the Glossators may have applied it, though there is too little evidence to say anything with any degree of certainty. The Commentators definitely used it, and even if the critical approach of Legal Humanism eroded its authority to some extent, the traditional method of the Commentators continued to be used, not only in Italy but elsewhere as well. The Usus Modernus is a somewhat modernised version of Roman law that incorporates part of the findings - especially textual corrections - of Legal Humanism. Roman law did, however, lose the self-evident imperial authority it had had during the Middle Ages due to its association with the emperor. The criticism of the Legal Humanists and natural lawyers meant that it eventually only applied to the extent that its intellectual content remained satisfactory. And to this extent it is often still present in modern codifications, albeit on the basis of a new authority.

The second point is the development from case law to codifications with a system of legal rules at a relatively high level of abstraction. Roman law in its classical form consisted of case law - a characteristic, incidentally, that it shares with modern common law. Both Justinian's Code and his Digest are collections of solutions of specific cases. In Roman times, these solutions did not have an automatic authority, as this would depend on the prestige of the author. ${ }^{57}$ However, they did play a part in future decision making that was similar to that of precedents in common law. During the reception process in the Middle Ages and later, Roman law was studied and treated in such a way that we eventually ended up with the civil law systems that we have today - which are, therefore, ultimately derived from a system based on case law. This is a very interesting evolution. From the preceding pages, we can see that there were probably two key contributing factors, one interior and one exterior. The interior factor starts in the medieval summae, where titles of the Corpus Iuris Civilis are treated in a systematic way. The grouping together of agreeing and contrasting texts around a sedes materiae made it easier to find the general rules and principles that were hidden behind the solutions to the cases. The rules and maxims of the last Digest title 50:17 (De diversis regulis iuris antiqui) were interpreted as a summary of the Digest in succinctly formulated rules and maxims that came to serve as general principles of law. And finally, the systematisation of the whole Corpus Iuris Civilis along the lines of the Institutiones made it possible to give all the rules and principles their logical place within a greater outline. ${ }^{58}$ The exterior factor is that canon law, moral theology and natural law tended to think much more in terms of general principles than Roman law did. Eventually this made possible the construction of systematic codifications of private law, in which a large amount of Roman law has found a place.

All this underlines that the transition to national codifications - accompanied by the abolition of Roman law as a source of law - was a real paradigm shift in European legal scholarship. The focus of attention for lawyers was now the codification. In some countries, Roman law retained a place in legal education; in others, like France and Belgium, the fixation on the codification was complete: the École de l'Exégèse. ${ }^{59}$ Still, this does not mean that the common heritage of Roman law is now sure to slowly fade into oblivion. On the contrary, it seems to be making some sort of comeback. As the European Union aims to achieve greater uniformity in law and a number of study groups analyse the differences among European systems of private law in order to try and develop a European Civil Code, Roman law is getting renewed attention as the common element, and even as a possible source of solutions for the future. ${ }^{60}$

\footnotetext{
57 Stein, above n. 6, at 2.

58 See also J.W. Cairns and P.J. du Plessis (eds.), The Creation of the Ius Commune: From Casus to Regula (Edinburgh 2008).

59 B. Bouckaert, De exegetische school: een kritische studie van de rechtsbronnen-en interpretatieleer bij de 19de eeuwse commentatoren van de Code Civil (Antwerp 1981).

60 R. Zimmermann, Roman Law, Contemporary Law, European Law: The Civilian Tradition Today (Oxford 2001).
} 